\title{
Air sacs (Sacci pneumatici) in mallard ducks (Anas platyrhynchos)
}

\author{
Aysun ÇEVİK DEMİRAN ${ }^{1}$, R. Merih HAZIROĞLU ${ }^{2}$, İbrahim KÜRTÜL ${ }^{3}$ \\ ${ }^{1}$ Department of Anatomy, Faculty of Veterinary Medicine, Kocatepe University, Afyon, Turkey; ${ }^{2}$ Department of Anatomy, Faculty \\ of Veterinary Medicine, Ankara University, Ankara, Turkey; ${ }^{3}$ Department of Anatomy, Faculty of Veterinary Medicine, Kafkas \\ University, Kars, Turkey.
}

Summary: This study aimed to observe the air sacs (Sacci pneumatici) in mature Mallard ducks (Anas platyrhynchos). After animals $(n=9)$ were euthanased by combination of ketamine $60 \mathrm{mg} / \mathrm{kg}$ and xylazine $6 \mathrm{mg} / \mathrm{kg}$, methylmethacrylate (Takilon) was injected by way of trachea. They were put in a cold-aired room for two months for polymerization. Then, they were maserated with $3 \%$ potassium hydroxide at $40{ }^{\circ} \mathrm{C}$, cleaned with tap water, coloured by glass dye and photographed. Morphology of the cervical and clavicular air sacs was consistent with previous studies. The cranial thoracic air sacs were smaller than the caudal sacs pneumatising the second to seventh ribs by their diverticula. The caudal thoracic air sac had no diverticulum. The left abdominal air sac had two portions, i.e. the cranial and caudal sacs; the latter aerating the last three ribs and synsacrum, the former being smaller and narrower. Moreover, the right abdominal air sac was bigger than the left sac.

Key words: Air sac, mallard duck.

\section{Yeşil başlı ördekte (Anas platyrhynchos) hava keseleri (Sacci pneumatici)}

Özet: Bu çalışma yeşil başlı ördekte (Anas platyrhynchos) hava keselerini (Sacci pneumatici) göstermeyi amaçladı. Hayvanlara $(n=9) 60 \mathrm{mg} / \mathrm{kg}$ ketamin ve $6 \mathrm{mg} / \mathrm{kg}$ ksilazin bileşimi ile ötenazi uygulandıktan sonra, trakea yoluyla metilmetakrilat (Takilon) şırıngayla verildi. Polimerizasyon için soğuk hava odasında iki ay bekletildi. Takiben $40^{\circ} \mathrm{C}$ 'de \%3'lük potasyum hidroksitle masere edilerek akar su altında temizlendi, cam boyası ile her bir hava kesesi ayrı renklerle boyandı ve fotoğrafı çekildi. Servikal ve klavikular hava keselerinin morfolojisi önceki çalışmalarla uyum gösterdi. Divertikulum tarafindan 2-7. kaburgaları havalandıran kranial torasik hava kesesi kaudal keselerden daha küçüktü. Kaudal torasik hava keselerinde divertikulum görülmedi. Sol abdominal hava kesesi kranial ve kaudal olmak üzere iki parçalıydı. Kaudal kısım son üç kaburga ve synsacrum'u havalandırdığı ve kranial keseden daha büyük ve geniş olduğu kayıt edildi. Ayrıca, sağ abdominal hava kesesi soldan daha büyük olduğu görüldü.

Anahtar sözcükler: Hava kesesi, yeşil başlı ördek.

\section{Introduction}

Air sacs in avian species besides respiration function have very important roles on the thermoregulation, regulation of the body weight during the flight, and voice production $(7,20)$. Not being directly related to each other, they are connected through the extrapulmonary extensions of the bronchi. These extending sacs invade around several visceral organs and into many of the skeleton bones in different levels $(6,8,12)$. The volume of the air sacs varies greatly among the species. Hence, it has been reported that the volume of the air sacs increases as the stretch of the muscles on the body wall changes (3).

There are five air sacs in mallard ducks namely; unpaired cervical sac, unpaired clavicular sac, paired cranial thoracic and caudal thoracic sacs, and paired abdominal sac $(15,16,18)$. The cervical sac extend up the neck on each side of the vertebral column as far as the axis. The clavicular sac has diverticula which extend around the heart and between the muscles and bones of the thoracic girdle and shoulder joint (15). The paired cranial thoracic sacs lie ventral to the lungs between the sternal ribs and the heart and liver. Whereas the paired caudal thoracic sacs lie more caudally between the body wall and the abdominal sacs (4). The abdominal sacs have perirenal diverticula which extend between the kidney and pelvis, and femoral diverticula which surround the head of the femur and penetrate between the thigh muscles (15)

Morphology of the air sacs in several avian species has been well documented $(11,14,17,19)$ however, studies on that in mallard ducks, found wide-spread all over the world, are very scarce $(1,13)$. This observation aimed to investigate the features of the air sacs, and document the differences if there is, and further expanding our knowledge with contribution to the literature.

\section{Material and Methods}

This study was carried out on 9 adult mallard ducks (4 female and 5 male) obtained from Ankara province. 
Methylmethacrylate (Takilon) was injected to all animals by way of trachea after euthanasia by intramuscular administration of ketamine $\mathrm{HCl} 60 \mathrm{mg} / \mathrm{kg}$ and xylazine 6 $\mathrm{mg} / \mathrm{kg}$ combination (17). Then, animals were kept in a cold room for two months for polymerization. Later, they were macerated with $3 \%$ potassium hydroxide at $40{ }^{\circ} \mathrm{C}$ for 48 hours as described by Taşbaş et al (18) and Taylor et al (19). They were rinsed with running tap water and dried at room temperature. Each sac was externally coloured with a glass dye in different colours using a fine pointing brush. The Nomina Anatomica Avium (2) was used for the nomenclature.

\section{Results}

The air sacs associated with the lungs were revealed by corrosion cast method and status of their diverticula were observed (Fig. 1/-A). No sexual differences associated with air sacs in ducks were noted in this study. The prominent features of each sac were described as follows.

\section{The cervical sac}

The cervical sac was bilaterally located lateral to the last two cervical and first two thoracal vertebras, and medial to the lungs (Fig. 1/-B). It communicated with the lungs via the first medio-ventral bronchi. The sac had three diverticula for associated areas. The vertebral diverticula, diverticula vertebralia, passing along the transversal and vertebral canals of the first two thoracal vertebras that extended up to the first cervical vertebra, were fully developed (Fig. 1/-B1). It also aerated the first two ribs. The intermuscular diverticula, diverticula intermuscularia, protruded in a spear like shape between the cervical vertebras and muscles, measuring approximately $1-2 \mathrm{~cm}$ long. The subcutaneous diverticula, diverticula subcutanea, were present cranio-dorsal to the clavicular sac.

The cervical sac aerated the first two thoracal and all the cervical vertebras except the first one. The last five thoracal vertebras, in contrast, were aerated directly by the lungs.

\section{The clavicular sac}

The clavicular sac was formed by the fusion of the bilaterally located diverticula under the trachea and attachment of the wings to the body (Fig. 1/-C). This sac had connection with the lungs through the third medioventral bronchi. The sac engulfed by the thoracal girdle, sternum, and heart occupied the entire cranial thoracic apertura.

The clavicular sac possessed six diverticula arranged intra- and extrathoracally. The cardiac diverticula, diverticula cardiaca, seen in front of the heart were merged on the median line (Fig. 2/-C5). The sternal diverticula, diverticula sternalia, the other intrathoracal diverticula, laid caudo-ventral direction to the former diverticula, aerating the sternum (Fig. 2/-C6).

Extrathoracal diverticula were observed around the cranial thoracic apertura. Among them were the subscapular diverticula, diverticulum subscapulare, which displayed leaf-like structures readily seen between the scapula and cervical sac (Figs. 1/-C1 and 2/-C1). Lateral to those the axillar diverticulum, diverticulum axillare, was observed beneath the shoulder muscles (Figs. 1/-C2 and 2/-C2). The subpectoral diverticulum, diverticulum subpectorale, extrathoracally located caudal to the first two diverticula, lateral to the first two ribs, and beneath the pectoral muscles (Figs. 1/-C3 and 2/C3). The last extrathoracal diverticulum was suprahumeral diverticulum, diverticulum suprahumerale, which was extended ventral to the axillar diverticulum, encircling the head of the humerus with its triangular shape (Figs. 1/-C4 and 2/-C4). This diverticulum aerating the humerus was the most developed of all.

\section{The cranial thoracic sac}

The cranial thoracic sac aerated by the first, second, and fourth medio-ventral bronchii was symmetrically located under the lateral wall of the body. It was rectangular in shape and larger than the caudal thoracic sac (Figs. 1/-D and 2/-D). It was found ventro-lateral to the lungs, medial to the sternal ribs, and lateral to the heart, liver and the caudal portion of the esophagus. This sac gave diverticula for the second to seventh sternal ribs for aeration.

\section{The caudal thoracic sac}

As for the cranial thoracic sac, the caudal thoracic sac was symmetrically located caudo-ventral to the lungs, receiving air via the fourth medio-ventral and first and second latero-ventral bronchii (Figs. 1/-E and 2/-E). It was almost two times larger than the cranial sac, having trace of the last four ribs. The caudal portion of the left caudal thoracic sac had relation with the gizzard. The caudal thoracic sac was encircled dorsally by the abdominal sac, and ventrally by the cranial thoracic sac, had no diverticulum.

\section{The abdominal sac}

The abdominal sac, occupying most of the coelom, was asymmetrically located as two parts in the abdomen (Figs. 1/-F and 2/-F). It extended from the caudal border of the lungs through the cloacae. This sac had connection with the lungs via the second, third, fourth, and fifth latero-ventral brochii. Its lateral surface was smooth while the medial surface was irregular in structure because of the viscera. The left abdominal sac was divided into cranial (Fig. 2/-F1) and caudal (Fig. 2/-F2) 


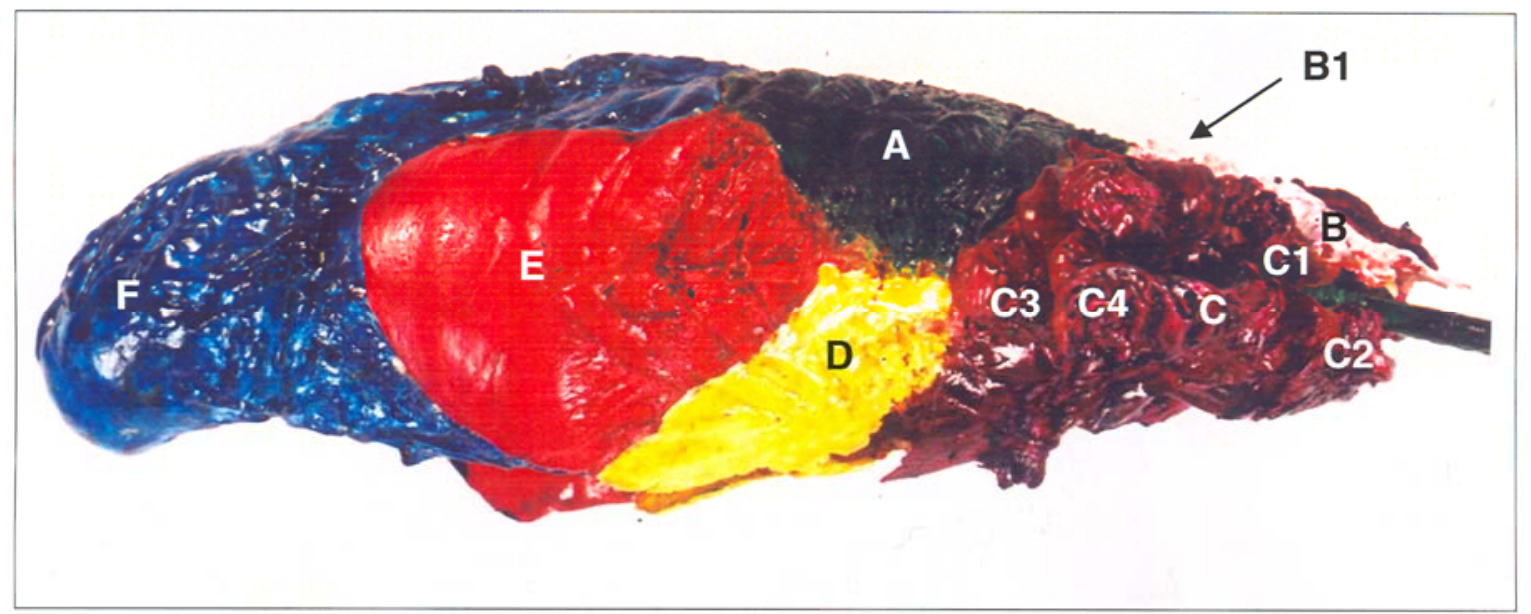

Figure 1. Right lateral view of the lungs and air sacs of the Mallard duck

A- Pulmo, B- Saccus cervicalis, B1- Diverticula vertebralia, C- Saccus clavicularis, C1- Diverticulum subscapulare, C2- Diverticulum axillare, C3- Diverticulum subpectorale, C4- Diverticulum suprahumerale, D- Saccus thoracicus cranialis, E- Saccus thoracicus caudalis, F- Saccus abdominalis.

Şekil 1. Yeşil başlı ördekte akciğerler ve hava keselerinin sağ yandan görünümü.

A- Pulmo, B- Saccus cervicalis, B1- Diverticula vertebralia, C- Saccus clavicularis, C1- Diverticulum subscapulare, C2Diverticulum axillare, C3- Diverticulum subpectorale, C4- Diverticulum suprahumerale, D- Saccus thoracicus cranialis, E- Saccus thoracicus caudalis, F- Saccus abdominalis.

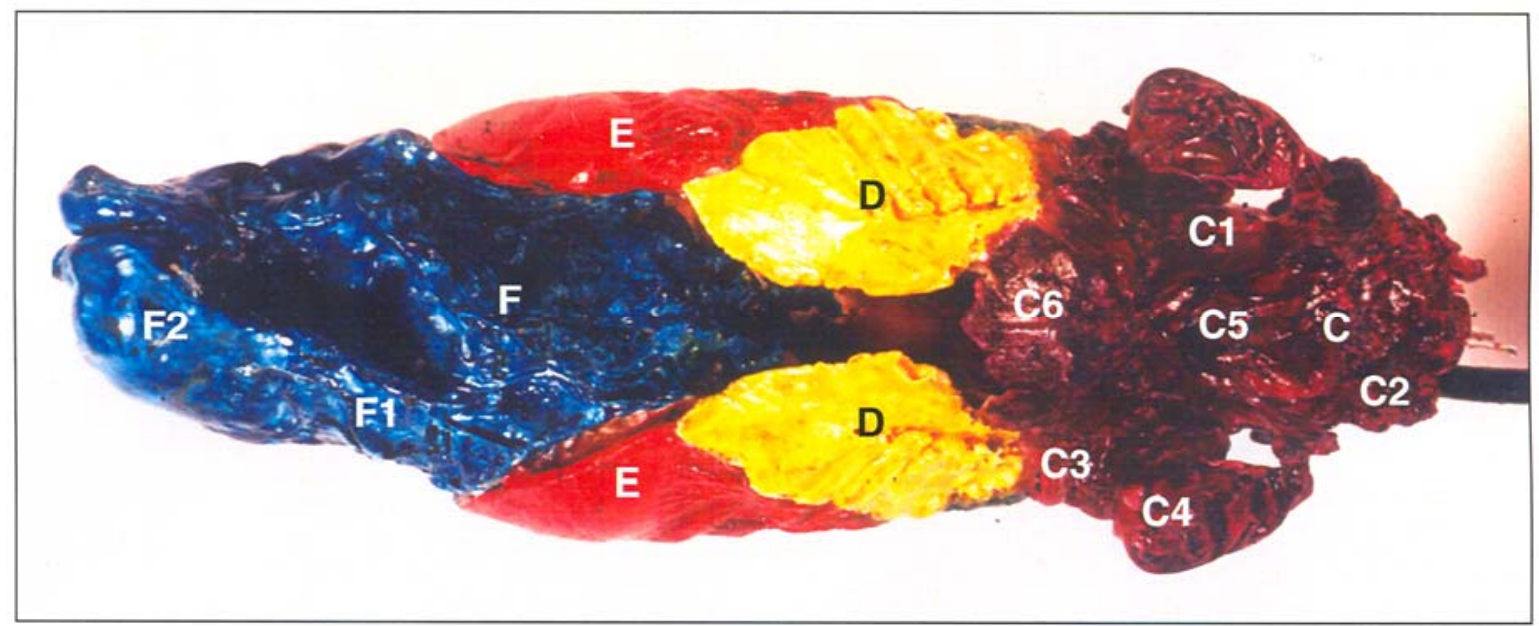

Figure 2. Ventral view of the lungs and air sacs of the Mallard duck.

C- Saccus clavicularis, C1- Diverticulum subscapulare, C2- Diverticulum axillare, C3- Diverticulum subpectorale, C4Diverticulum suprahumerale, C5- Diverticula cardiaca, C6- Diverticula sternalia, D- Saccus thoracicus cranialis, ESaccus thoracicus caudalis, F- Saccus abdominalis, F1- Saccus abdominalis (pars cranialis), F2- Saccus abdominalis (pars caudalis).

Şekil 2. Yeşil başlı ördekte akciğerler ve hava keselerinin ventralden görünümü.

C- Saccus clavicularis, C1- Diverticulum supscapulare, C2- Diverticulum axillare, C3- Diverticulum subpectorale, C4- Diverticulum suprahumerale, C5- Diverticula cardiaca, C6- Diverticula sternalia, D- Saccus thoracicus cranialis, E- Saccus thoracicus caudalis, F- Saccus abdominalis, F1- Saccus abdominalis (pars cranialis), F2- Saccus abdominalis (pars caudalis).

portions. The cranial portion aerated the last three ribs and synsacrum and medially possessed a trace of the gizzard whereas the caudal portion was smaller and narrower than the cranial portion. The right abdominal sac was longer than the left one and its body was narrower than the caudal end, comprising traces of the intestines.

\section{Discussion and Conclusion}

The most striking finding of this study was that no sex differences were observed among the duck studied.

Findings of the study were consistent with those documented in the literature in general $(7,12,20)$. However, if individually compared, the air sacs of the mallard duck showed great differences. 
The cervical sac with its diverticula was similar to what was reported in previous studies $(12,20)$. It was clearly demonstrated, in this study, that the second cervical bone, axis, and the first two ribs were aerated by this sac in the mallard duck. This was dissimilar to other species like domestic chickens $(5,9)$.

Location and number of the diverticula of the clavicular sac was consistent with the literature $(7,12$, 20). On the contrary, it was notable that the suprahumeral diverticulum giving air to the humerus was highly developed as compared to the other extrathoracal diverticulum.

The cranial thoracic diverticula which were reported not to aerate any bones and not to possess any diverticula (10), but in this study, it gave diverticula for the second to seventh ribs. Additionally, the caudal thoracic sac was absent in white Pekin duck (13) was present in the mallard duck, having no diverticula for aeration of any bone. With these features, the caudal thoracic sac in the mallard duck was similar to those described in the Nomina Anatomica Avium (2).

Tasbas et al (18) showed that in Denizli cock the cranial thoracic sac was larger than the caudal one, in contrast to our findings.

The left abdominal sac in this study was divided into two portions i.e. cranial and caudal portions. To our knowledge no data similar to this has been previously reported in the literature. The cranial portion aerated the last three ribs and synsacrum. The caudal portion was smaller and narrower, giving no diverticula for any bone.

The right abdominal sac in mallard ducks was longer than the left one, similar to the studies of King (10), King and McLelland (12), and Vollmerhaus and Sinowatz (20) but in contrary with the findings of Tasbas et al (18).

In conclusion, gross morphology of the air sacs in the mallard duck was closely examined and similarities and dissimilarities with the literature were documented.

\section{Acknowledgements}

The authors would like to thank Associate Prof Dr İbrahim DEMIRKAN of Department of Surgery, Faculty of Veterinary Medicine, Kocatepe University, Afyon, Turkey for his valuable discussion and carefully reading the manuscript.

\section{References}

1. Akester AR (1960): The comparative anatomy of the respiratory pathways in the domestic fowl (Gallus domesticus), pigeon (Colomba livia) and domestic duck (Anas platyrhyncha). J Anat, 94, 487-505.

2. Baumel JJ, King AS, Breazile JE, Evans HE, Vanden Berge JC (1993): Nomina Anatomica Avium. The Nuttall Ornithological Club. No: 23, Cambridge, Massachusetts.
3. Butler PJ, Bishop CM (2000): Flight. 391-430. In: GC Whittow (Ed), Sturkie's Avian Physiology, $5^{\text {th }}$ ed., Academic Press, New York.

4. Dyce KM, Sack WO, Wensing CSG (1996): Textbook of Veterinary Anatomy. $2^{\text {th }}$ W.B. Saunders Company, Philadelphia.

5. Hogg DA (1984): The distribution of pneumatisation in the skeleton of the adult domestic fowl. J Anat, 138, 617-629.

6. Hogg DA (1990): The development of pneumatisation in the skull of the domestic fowl. J Anat, 169, 139-151.

7. King AS (1975): Respiratory system. 1857-1882. In: R Getty (Ed), Sisson and Grossman's The Anatomy of the Domestic Animals, $5^{\text {th }}$ ed., W. B. Saunders Company, New York.

8. King AS, Kelly DF (1956): The aerated bones of Gallus domesticus: the fifth thoracic vertebra and sternal ribs. Brit Vet J, 112, 279-283.

9. King AS (1957): The aerated bones of Gallus domesticus. Acta Anat, 31, 220-230.

10. King AS (1993): Systema respiratorium. 281-282. In: JJ Baumel (Ed), Handbook of Avian Anatomy, Nomina Anatomica Avium, Cambridge Press.

11. King AS, Payne DC (1962): The maximum capacities of the lungs and air sacs of Gallus domesticus. J Anat, 96, 495-503.

12. King AS, McLelland J (1984): Respiratory system. 110144. In: AS King, J Mclelland (Eds), Birds: Their structures and function. $2^{\text {nd }}$ ed., Bailliere \& Tindal, London.

13. Lucas AH, Keeran RJ, Coussens C (1959): Air sacs of chicken, turkey, duck and owl. Anat Rec, 133, 452.

14. Mannega A, Calhoun ML (1968): Morphology of the lower respiratory structures of the white Pekin duck. Poultry Sci, 47, 266-280.

15. McLelland J (1990): Respiratory system. 95-119. In: A Colour Atlas of Avian Anatomy. Published by Wolfe Publishing Ltd. England.

16. Nickel R, Schummer A, Seiferle E (1997): Anatomy of the Domestic Birds. Translations by W.G. Siller, P.A.L. Wight, Verlag Paul Parey, Berlin-Hamburg.

17. Rigdon RH, Ferguson TM, Feldman GL, Couc JR (1958): Air sacs in the turkey. Poultry Sci, 37, 53-60.

18. Taşbaş M, Hazıroğlu RM, Çakır A, Özer M (1994): Morphology of the respiratoric system in Denizli cocks. Ankara Üniv Vet Fak Derg, 41, 154-168.

19. Taylor RO, Bcone MA, Barnett BD (1962): Plastic infusion and casting of the avian air sacs. Poultry Sci, 41, 1940-1943.

20. Vollmerhaus B, Sinowatz F (1992): Luftsäcke. 172-174. In: R Nickel, A Schummer, E Seiferle (Eds), Lehrbuch der Anatomie der haustiere, Berlin, Verlag Paul Parey.

Geliş tarihi : 19.09.2005 / Kabul tarihi: 01.12.2005
Adress for correspondance
Yrd. Doç. Dr. Aysun Çevik Demirkan
Kocatepe Üniversitesi
Veteriner Fakültesi
Anatomi Anabilim Dalı
03200 - Afyon, Türkiye
E-mail:aysuncevik@yahoo.comT 